\title{
ERYTHROCYTE GLUCOSE-6-PHOSPHATE DEHYDROGENASE DEFICIENCY: EVIDENCE OF DIFFERENCES BETWEEN NEGROES AND CAU- CASIANS WITH RESPECT TO THIS GENETICALLY DETERMINED TRAIT *
}

\author{
By PAUL A. MARKS AND RUTH T. GROSS
}

\author{
(From the Department of Medicine, Columbia University College of Physicians and Surgeons, \\ Medical Services of the Francis Delafield and The Presbyterian Hospitals, New \\ York City, and the Department of Pediatrics, Stanford University School of \\ Medicine, Pediatric Service of the Stanford University Hospital, \\ Palo Alto, Calif.)
}

(Submitted for publication August 7, 1959; accepted September 1, 1959)

Erythrocyte glucose-6-phosphate dehydrogenase (G-6-P.D.) deficiency is associated with an increased susceptibility to hemolysis following ingestion of such agents as primaquine, naphthaline, sulfonamides, other drugs and the fava bean (1, $2)$. The incidence of this trait varies considerably among different population groups. Thus, it is relatively common among Negroes (3-7) and among Caucasians of Italian $(4,5)$, Greek $(4,5$, 8 ) and Sephardic Jewish (9) extraction. On the other hand, the incidence of erythrocyte G-6-P.D. deficiency is low among subjects of Chinese (10) and Javanese (7) descent and is particularly rare among Ashkenazy Jews (9) and certain other Western Europeans (1-5). Data accumulated in both Negro $(4,5)$ and Caucasian populations $(4,5,9)$ have suggested that this erythrocyte enzyme deficiency is due to a sex-linked gene of intermediate dominance.

It has been assumed that the deficiency in G-6P.D. in these various population groups is a result of the same gene mutation. The explanation of the varied incidence of this enzyme defect in different racial groups has remained an intriguing problem.

The present investigation has been concerned with further characterization of the relationship between the gene alteration and the resulting deficiency in red blood cell G-6-P.D. Among subjects with low erythrocyte G-6-P.D. activity, Caucasian males were found to have a more marked deficiency of this enzyme than Negro males. Recently, it was reported (11) that $\mathrm{Ne}-$

* This work was supported in part by Grant C2332 of the National Cancer Institute, National Institutes of Health, and Grant RG-4754 of the United States Public Health Service. gro subjects with erythrocyte G-6-P.D. deficiency had normal levels of this enzyme in their leukocytes. It has now been found that affected ${ }^{1}$ Caucasian males have significantly lower than normal activities of G-6-P.D. in their leukocytes.

Among affected subjects, the deficiency in G-6-P.D. activity is more marked in red blood cells than in leukocytes. In persons with normal erythrocyte G-6-P.D. activity, the level of this enzyme decreases with the in vivo aging of the red blood cells (12). In the present study the effect of age on erythrocyte G-6-P.D. activity has been examined in affected subjects. Enzyme activity was assayed in young and old red cell fractions separated by serial osmotic hemolysis or by centrifugation. G-6-P.D. activity in young red cells was found to be higher among affected Negro males than affected Caucasian males, and to decrease with the in vivo aging of the erythrocytes.

\section{METHODS}

Subjects studied. All subjects had normal values for hemoglobin concentrations and erythrocyte, reticulocyte, leukocyte and platelet counts with the exceptions of the patients with chronic hemolytic anemia (Table I) and those with reticulocytosis (Table IV). The subjects studied with erythrocyte G-6-P.D. deficiency are indicated in Footnotes $\dagger$ and $\ddagger$ of Table $I$. The control group included subjects selected at random from among hospital personnel and patients. Fifty-nine of the subjects included in Table I, and 31 of the control and 14 of the "deficient" Negro group included in Table II, represent persons previously reported $(5,11)$.

Enzyme assays. G-6-P.D. was assayed by a method based on that of Kornberg and Horecker (13). The details of this enzyme assay have been described else-

1 The term "affected" is used to denote subjects with erythrocyte glucose-6-phosphate dehydrogenase activities below 3.0 standard deviations of the control mean value. 
where (14). A unit of G-6-P.D. activity in erythrocytes was defined as a change in one optical density unit per minute per gram of hemoglobin. Enzyme activity in erythrocytes was referred to hemoglobin concentration rather than cell count or cell volume because this parameter was found to provide most reproducible results (14, 15). A unit of G-6-P.D. activity in leukocytes was defined as the change in one optical density unit per minute per $10^{\circ}$ cells. Prior to hemolysis of erythrocyte samples or disruption of white cell samples, aliquots of the suspended cells were removed for counting of erythrocytes, leukocytes and, when appropriate, reticulocytes and platelets. Hemoglobin concentrations were measured as previously described (12).

Preparation of cells. Venous blood, mixed with heparin to prevent clotting, was employed for all studies. Hemolysates of washed erythrocytes were prepared from the blood for enzyme assay as previously described (14). The washed erythrocytes were contaminated with fewer than 0.05 per cent leukocytes.

For studies in which enzyme activity was determined in both leukocytes and erythrocytes, venous blood was drawn into siliconized syringes and transferred to siliconized test tubes. The blood cells were separated by a method of dextran flotation (16) which was carried out at $4^{\circ} \mathrm{C}$. The whole blood was added to an equal volume of 3 per cent dextran and 3 per cent glucose in 0.9 per cent sodium chloride and allowed to sediment for 30 to 45 minutes. The supernatant plasma, containing leukocytes and platelets with relatively few red cells, was removed and centrifuged at $800 \times \mathrm{G}$ for eight minutes. The sedimented white cells were recovered and suspended in approximately 20 volumes of isotonic potassium chloride buffered at $\mathrm{pH} 7.4$ with potassium bicarbonate. The leukocytes were disrupted by freezing and thawing four times. Leukocyte counts were performed prior to and following this procedure to insure that assays were performed only on samples in which more than 90 per cent of the white cells were destroyed. This procedure yielded a leukocyte preparation contaminated with fewer than five red cells and less than one platelet for each white cell. This degree of contamination by erythrocytes and platelets had no detectable effect on the assays of leukocyte enzyme.

The erythrocytes, following sedimentation in dextran, were centrifuged at $1,000 \times G$ for 10 minutes. The supernatant was removed and the red cells washed twice with isotonic potassium chloride buffered at $\mathrm{pH} 7.4$ and resuspended in this solution. The erythrocyte samples prepared in this manner were contaminated with less than 0.03 per cent leukocytes and 0.5 per cent platelets. This degree of contamination by platelets had no detectable effect on the red cell enzyme assays. However, a detetcable level of G-6-P.D. was attributable to the leukocytes in these erythrocyte samples. The enzyme activity attributable to the leukocytes was calculated by multiplying the number of leukocytes in the erythrocyte sample by the enzyme activity per white cell. Among 82 subjects with a mean erythrocyte G-6-P.D. of $16: 1 \pm 2.4$ units, ${ }^{2}$ the enzyme activity attributable to leukocytes present in these red cell samples averaged $0.4 \pm 0.2$ unit. In 45 affected persons with an average red cell G-6-P.D. of $2.1 \pm 1.6$ units, G-6-P.D. attributable to leukocytes averaged $0.2 \pm 0.15$ unit. This method of correcting the erythrocyte enzyme activity for leukocyte contamination probably overestimated the contribution of the white cell enzyme. The erythrocytes were hemolyzed by freezing and thawing twice. This procedure usually disrupted only 60 to 75 per cent of the leukocytes. In addition, in seven Caucasian persons (included in Table I) there was no detectable red cell G-6-P.D. despite the fact that these samples were contaminated with 0.007 to 0.03 per cent leukocytes. These data indicate that the error in determining red cell G-6-P.D. activity attributable to white cell contamination was small.

Separation of young and old erythrocytes. The resuspended washed erythrocytes (to be referred to as the whole erythrocyte population) were separated into fractions of relatively young and old mean ages by two different methods : $a$ ) serial osmotic hemolysis and $b$ ) centrifugation.

a) Serial osmotic hemolysis: The method of graded osmotic hemolysis employed for the separation of the whole erythrocyte population into fractions of differing mean cell age has been previously described (17). This method is based on the fact that young mature human erythrocytes are more resistant to hemolysis in hypoIonic media than old cells.

b) Centrifugation: A modification of previously published methods of separating the whole erythrocyte population into fractions of relatively young and old cells was employed $(12,18)$. This method is based on the fact that young red cells are less dense than old cells. Approximately $25 \mathrm{ml}$. of the whole erythrocyte population was centrifuged at $1,900 \times \mathrm{G}$ for 45 minutes in siliconized glass tubes of inner dimensions $7 \times 145 \mathrm{~mm}$. The upper 10 per cent and the lower 10 per cent of red cells, respectively, from each tube were combined and resuspended in isotonic potassium chloride buffered at $\mathrm{pH}$ 7.4. These samples were again centrifuged at $1,900 \times \mathrm{G}$ for $45 \mathrm{~min}$ utes, and the top 15 per cent of the upper red cell sample and the bottom 15 per cent of the lower red cell sample were recovered and washed once with potassium chloride buffered at $\mathrm{pH} 7.4$ and resuspended in this solution. Aliquots of each sample were taken for cell counts, hemoglobin determination and enzyme assay.

\section{RESULTS}

\section{Erythrocyte glucose-6-phosphate dehydrogenase activity}

In a group of 500 adult subjects the erythrocyte G-6-P.D. activity was $16.1 \pm 2.2$ units. Among this control group no significant differences were found between the mean values for red cell G-6-

\footnotetext{
2 The mean value \pm on standard deviation.
} 
P.D. of males compared with females, or Caucasians compared with Negroes. Subjects whose level of dehydrogenase in erythrocytes was less than 3.0 standard deviations below the control mean were considered to have a deficiency of G-6-P.D.

The activity of erythrocyte G-6-P.D. among affected Negro males was $2.7 \pm 1.5$ units compared with $0.4 \pm 0.4$ unit for deficient Caucasian males (Table I). The difference between these means was statistically highly significant, 11 times the standard error of the difference. The average red cell G-6-P.D. level for the group of affected Negro females was $6.9 \pm 2.3$ units compared to $6.8 \pm 3.2$ units for affected Caucasian females (Table I). The difference between these means was not statistically significant.

TABLE I

Erythrocyte glucose-6-phosphate dehydrogenase activity among subjects with a deficiency of this enzyme

\begin{tabular}{lcccc}
\hline \hline & & \multicolumn{3}{c}{$\begin{array}{c}\text { Erythrocyte glucose-6-phosphate } \\
\text { dehydrogenase* }\end{array}$} \\
\cline { 3 - 6 } Subject & No. & Mean & Range & S. D. \\
\hline $\begin{array}{l}\text { Negroł } \\
\text { Male }\end{array}$ & 59 & 2.7 & $0.7-6.0$ & 1.5 \\
Female & 52 & 6.9 & $2.0-9.5$ & 2.3 \\
Caucasian & & & & \\
Male & 22 & 0.4 & $0-1.1$ & 0.4 \\
Female & 22 & 6.8 & $0-9.6$ & 3.2 \\
\hline
\end{tabular}

* Enzyme activity is expressed as the change in optical density units per minute per gram hemoglobin.

† Negro male subjects include: a) 24 persons without known hematological disorders who were discovered during a random population survey and 11 relatives of such subjects; $b$ ) 6 persons with a history of hemolytic anemia following ingestion of naphthaline and 8 relatives of such subjects ; c) 1 person with a history of favism; d) 6 persons with a history of acute hemolytic anemia of undetermined cause and 3 relatives of such subjects. Negro female subjects include: a) 19 persons without known hematological disorders who were discovered during a random population survey and 14 relatives of such subjects; $b$ ) 1 person with a history of acute hemolytic anemia following ingestion of naphthaline and 10 relatives of such subjects; c) 2 relatives of subjects with a history of favism; d) 6 relatives of subjects with a history of acute hemolytic anemia of undetermined cause.

¥ Caucasian male subjects include: $a$ ) 4 persons with a history of favism and 7 relatives of such subjects; $b$ ) 3 persons with a history of hemolytic anemia following the ingestion of sulfonamides and 2 relatives of such a subject ; c) 2 persons with a history of acute hemolytic anemia of undetermined cause; d) 2 persons with chronic hemolytic anemia of undetermined cause and 2 relatives of such subjects. Caucasian female subjects include: $a) 2$ persons without known hematological disorders who were discovered during a random population survey; b) 2 persons with a history of favism and 12 relatives of such subjects c) 4 relatives of subjects with a history of acute hemolytic anemia of undetermined etiology ; d) 2 relatives of subjects with chronic hemolytic anemia of undetermined etiology.
TABLE II

\begin{tabular}{|c|c|c|c|c|}
\hline \multirow[b]{2}{*}{ Subject } & \multirow[b]{2}{*}{ No. } & \multicolumn{3}{|c|}{$\begin{array}{l}\text { Leukocyte glucose-6-phosphate } \\
\text { dehydrogenase* }\end{array}$} \\
\hline & & Mean & Range & S. D. \\
\hline Controlt & 85 & 44.4 & $19.2-99.8$ & 19.3 \\
\hline $\begin{array}{l}\text { Negro } \\
\text { Caucasian }\end{array}$ & $\begin{array}{l}48 \\
37\end{array}$ & $\begin{array}{l}46.8 \\
42.1\end{array}$ & $\begin{array}{l}22.9-99.8 \\
19.2-64.4\end{array}$ & $\begin{array}{l}22.0 \\
13.0\end{array}$ \\
\hline \multicolumn{5}{|l|}{ Deficient } \\
\hline $\begin{array}{l}\text { Negro } \\
\text { Caucasian }\end{array}$ & $\begin{array}{l}38 \\
17\end{array}$ & $\begin{array}{l}38.1 \\
14.0\end{array}$ & $\begin{array}{r}26.2-63.0 \\
6.1-23.4\end{array}$ & $\begin{array}{r}11.6 \\
5.9\end{array}$ \\
\hline
\end{tabular}

* Enzyme activity is expressed as change in optical density units per minute per $10^{\circ}$ leukocytes.

$\dagger$ The mean \pm standard deviation for erythrocyte glucose-6-phosphate dehydrogenase activity of the control Negro group was $16.2 \pm 2.3$ units and for the control Caucasian group, $16.1 \pm 2.5$ units.

$\ddagger$ All subjects included in this group had erythrocyte glucose-6-phosphate dehydrogenase activity .below 4.5 standard deviations of the control mean value.

Subjects with erythrocyte G-6-P.D. deficiency may be divided arbitrarily into two groups: a moderately deficient group, with values of red cell enzyme between 3 and 4.5 standard deviations below the control mean; and a severely deficient group, with enzyme activities lower than 4.5 standard deviations from the control means. The group of Negroes with a moderate deficiency in G-6-P.D. included 45 females and no males, while those with a severe deficiency of the red cell enzyme included 59 males and 7 females. In the group of affected Caucasians, those with a moderate deficiency included 19 females and no males and those with a severe deficiency included 22 males and 3 females. This preponderance of females among moderately affected subjects and of males among severely affected persons is in agreement with several previously published observations $(4,5,9,19)$. This observation is consistent with the suggestion that this trait is due to a sex-linked gene of intermediate dominance $(4,5,9)$.

\section{Leukocyte glucose-6-phosphate dehydrogenase}

In Negro subjects with marked red cell G-6P.D. deficiency, the activity of this enzyme in leukocytes was not significantly different from that in white cells of the control group (Table II). ${ }^{-}$This finding is in agreement with an earlier report based on a smaller number of observations (11). 
TABLE III

Glucose-6-phosphate dehydrogenase activity in erythrocyte fractions of different age separated on the basis of varying osmotic fragility: subjects with normal erythrocyte glucose-6-phosphate dehydrogenase

\begin{tabular}{|c|c|c|c|c|c|c|c|c|c|c|c|}
\hline \multicolumn{6}{|c|}{ Negroes } & \multicolumn{6}{|c|}{ Caucasians } \\
\hline \multirow[b]{3}{*}{$\begin{array}{l}\text { Subject } \\
\text { No. }\end{array}$} & \multirow[b]{3}{*}{ WEP* } & \multicolumn{4}{|c|}{ Osmotic resistance† } & \multirow[b]{3}{*}{$\begin{array}{l}\text { Subject } \\
\text { No. }\end{array}$} & \multirow[b]{3}{*}{ WEP } & \multicolumn{4}{|c|}{ Osmotic resistance } \\
\hline & & \multicolumn{2}{|c|}{ Most } & \multicolumn{2}{|c|}{ Least } & & & \multicolumn{2}{|c|}{ Most } & \multicolumn{2}{|c|}{ Least } \\
\hline & & $\begin{array}{c}\% \\
\text { cells }\end{array}$ & G-6-P.D. & $\begin{array}{c}\% \\
\text { cells }\end{array}$ & G-6-P.D. & & & $\begin{array}{c}\% \\
\text { cells }\end{array}$ & G-6-P.D. & $\begin{array}{c}\% \\
\text { cells }\end{array}$ & G-6-P.D. \\
\hline $\begin{array}{r}1 \\
2 \\
3 \\
4 \\
5 \\
6 \\
7 \\
8 \\
9 \\
10 \\
11 \\
12 \\
13 \\
14 \\
15 \\
16 \\
17 \\
18 \\
19\end{array}$ & $\begin{array}{l}12.3 \\
17.3 \\
15.5 \\
20.9 \\
12.8 \\
14.3 \\
16.6 \\
15.9 \\
18.4 \\
14.3 \\
16.8 \\
14.2 \\
16.4 \\
15.1 \\
16.9 \\
16.0 \\
15.5 \\
14.6 \\
13.1\end{array}$ & $\begin{array}{l}5 \\
2 \\
5 \\
2 \\
5 \\
3 \\
4 \\
3 \\
1 \\
5 \\
5 \\
7 \\
2 \\
4 \\
2 \\
2 \\
3 \\
3 \\
3\end{array}$ & $\begin{array}{l}18.0 \\
33.6 \\
26.9 \\
36.0 \\
28.5 \\
31.2 \\
36.0 \\
30.2 \\
45.0 \\
38.4 \\
38.4 \\
31.2 \\
45.2 \\
33.6 \\
45.2 \\
41.9 \\
31.9 \\
26.2 \\
42.8\end{array}$ & $\begin{array}{l}5 \\
5 \\
2 \\
4 \\
3 \\
4 \\
3 \\
3 \\
\vdots \\
3 \\
\vdots \\
2 \\
4 \\
\ddagger \\
+ \\
2 \\
3 \\
\ddagger \\
3\end{array}$ & $\begin{array}{c}5.2 \\
5.8 \\
1.2 \\
6.1 \\
3.2 \\
4.9 \\
4.2 \\
4.1 \\
\ddagger \\
4.4 \\
\vdots \\
6.7 \\
2.4 \\
\ddagger \\
\ddagger \\
2.0 \\
5.6 \\
\ddagger \\
7.2\end{array}$ & $\begin{array}{l}20 \\
21 \\
22 \\
23 \\
24 \\
25 \\
26 \\
27 \\
28 \\
29 \\
30 \\
31 \\
32 \\
33 \\
34 \\
35 \\
36 \\
37 \\
38 \\
39 \\
40 \\
41 \\
42 \\
43 \\
44 \\
45 \\
46 \\
47 \\
48\end{array}$ & $\begin{array}{l}16.8 \\
14.0 \\
13.3 \\
15.2 \\
19.9 \\
12.1 \\
16.3 \\
12.7 \\
12.0 \\
13.2 \\
15.7 \\
15.6 \\
15.1 \\
15.5 \\
18.0 \\
13.1 \\
17.9 \\
13.4 \\
13.8 \\
17.2 \\
14.6 \\
14.2 \\
13.0 \\
17.8 \\
14.4 \\
12.2 \\
15.8 \\
13.7 \\
16.2\end{array}$ & $\begin{array}{l}2 \\
3 \\
2 \\
5 \\
5 \\
5 \\
2 \\
2 \\
2 \\
2 \\
2 \\
3 \\
2 \\
5 \\
5 \\
2 \\
5 \\
3 \\
3 \\
4 \\
4 \\
3 \\
4 \\
2 \\
2 \\
5 \\
5 \\
3 \\
3\end{array}$ & $\begin{array}{l}34.8 \\
40.8 \\
25.2 \\
19.3 \\
39.8 \\
26.7 \\
38.3 \\
28.5 \\
40.2 \\
29.8 \\
23.5 \\
23.6 \\
31.6 \\
22.3 \\
39.6 \\
31.2 \\
38.4 \\
22.8 \\
39.6 \\
30.0 \\
40.0 \\
39.6 \\
27.6 \\
32.4 \\
38.4 \\
21.4 \\
18.6 \\
40.2 \\
33.0\end{array}$ & 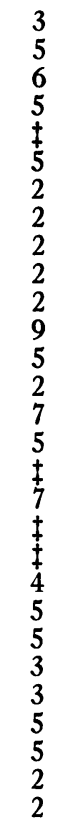 & $\begin{array}{c}7.5 \\
5.5 \\
5.0 \\
4.2 \\
\ddagger \\
2.6 \\
1.7 \\
3.4 \\
2.1 \\
49 \\
1.2 \\
5.0 \\
5.2 \\
1.8 \\
6.4 \\
4.6 \\
\ddagger \\
4.5 \\
\ddagger \\
\ddagger \\
7.9 \\
8.9 \\
7.9 \\
7.4 \\
8.8 \\
3.4 \\
5.9 \\
6.1 \\
4.7\end{array}$ \\
\hline $\begin{array}{l}\text { M } \\
\text { S. D. }\end{array}$ & $\begin{array}{r}15.6 \\
2.1\end{array}$ & $\begin{array}{l}3 \\
2\end{array}$ & $\begin{array}{r}34.7 \\
7.2\end{array}$ & $\begin{array}{l}3 \\
1\end{array}$ & $\begin{array}{l}4.5 \\
1.7\end{array}$ & $\begin{array}{l}\text { M } \\
\text { S. D. }\end{array}$ & $\begin{array}{r}14.9 \\
2.0\end{array}$ & $\begin{array}{l}3 \\
1\end{array}$ & $\begin{array}{r}31.6 \\
7.3\end{array}$ & $\begin{array}{l}4 \\
2\end{array}$ & $\begin{array}{l}5.0 \\
2.0\end{array}$ \\
\hline
\end{tabular}

*Abbreviations: WEP, whole erythrocyte population; G-6-P.D., glucose-6-phosphate dehydrogenase. Enzyme activity is expressed as change in optical density units per minute per gram hemoglobin; $M$, mean value; S. D., standard deviation.

t In each fractionation the red cell sample obtained which was most resistant to hypotonic hemolysis (relatively young cells) and that which was least resistant to hypotonic hemolysis (relatively old cells) were assayed for glucose-6phosphate dehydrogenase activity. The \% cells refers to the percentage of the whole erythrocyte population in these fractions most and least osmotically fragile.

$\ddagger$ No sample obtained for analysis.

It is to be noted, however, that the level of leukocyte dehydrogenase in these affected Negroes tended to be in the lower range of normal.

In contrast to these findings, Caucasians with a marked deficiency of erythrocyte enzyme had a mean value for white cell G-6-P.D. significantly lower than that of both the control Caucasian group and the deficient Negro subjects. The difference between the means for leukocyte G-6-P.D. activity of the affected Caucasians compared with the control group and with the affected Negro group was 10.9 and 10.2 times the standard error of the difference, respectively.

In seven Negro females whose erythrocyte
G-6-P.D. activity was moderately decreased, the level of this enzyme in their leukocytes was within the range of values for the control group. No data were obtained for leukocyte G.-6.P.D. activities in Caucasians with a moderate decrease in erythrocyte enzyme.

\section{Enzyme activity in erythrocytes fractionated by serial osmotic hemolysis}

In red cells fractionated by serial osmotic hemolysis, the most resistant and least resistant cell fractions have relatively younger and older mean cell ages, respectively. Accordingly, the enzyme activities may be related to the relative mean age 
TABLE IV

Glucose-6-phosphate dehydrogenase activity in erythrocyte fractions of different age separated on the basis of varying osmotic fragility: subjects with deficient erythrocyte glucose-6-phosphate dehydrogenase

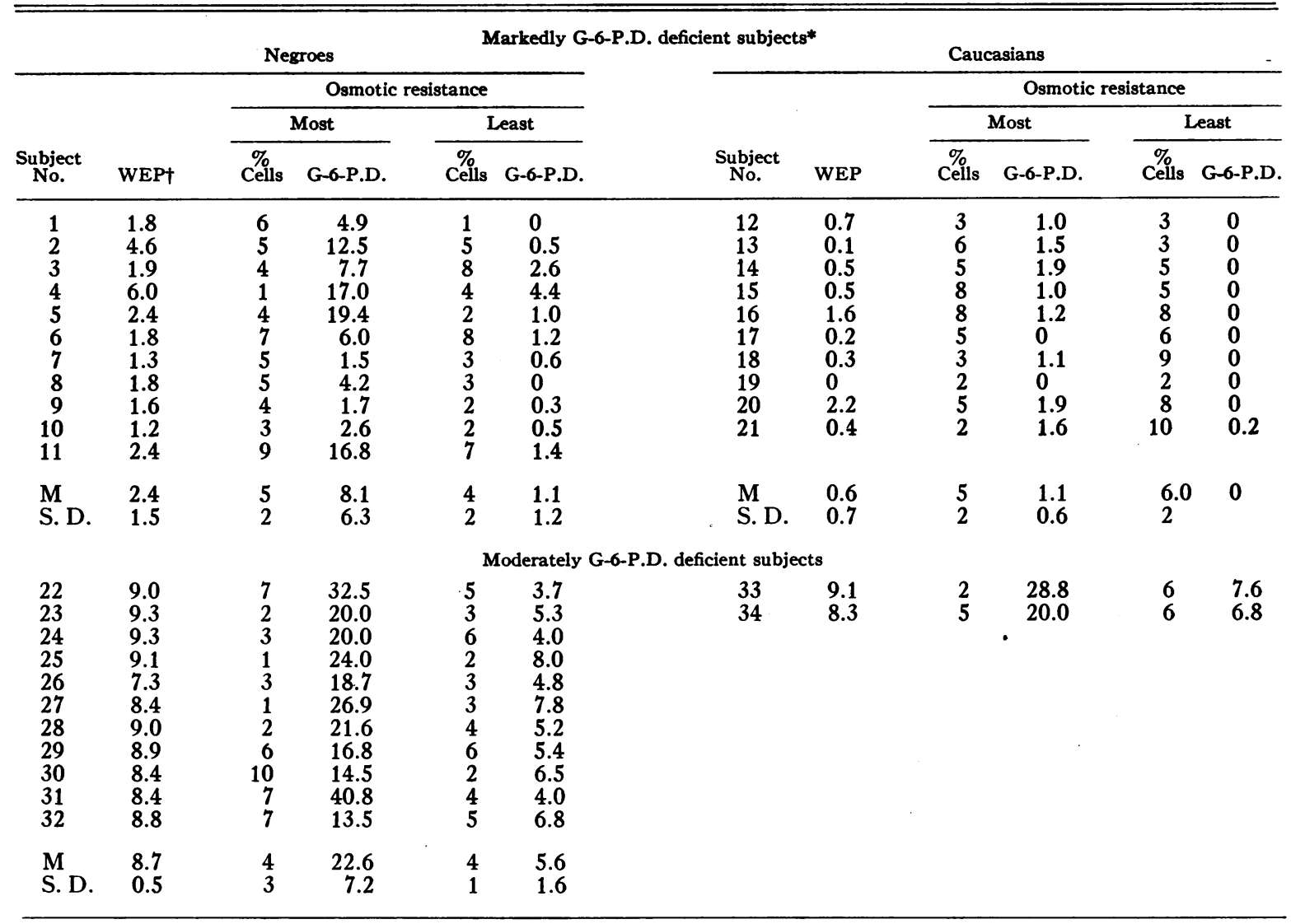

* Markedly G-6-P.D. deficient subjects included persons whose erythrocyte enzyme activity was below 4.5 standard deviations of the control mean. Moderately G-6-P.D. deficient subjects included persons whose erythrocyte enzyme activity was 3.0 to 45 standard deviations below the control mean.

$\dagger$ See Footnotes ${ }^{*}$ and $\dagger$, Table III.

of the red blood cells in the various fractions. Among normal subjects the activity of G-6-P.D. was markedly higher in the younger than in the older erythrocyte fractions (Table III). The mean value for enzyme activity in the younger fraction exceeded that in the older cells by factors of 7.7 and 6.3 for the control group of Negroes and of Caucasians, respectively. There was variation among different subjects in the enzyme activity in erythrocyte fractions of the same osmotic resistance. This variation is attributable, in part, to the fact that such erythrocyte fractions prepared from red cell populations of different subjects vary in the degree of relative enrichment with young and old cells (17). However, in a given fractionation study, it was consistently observed that the older the relative mean cell age of the erythrocyte sample, the lower the activities of G-6-P.D. (12).

In Negroes with a marked erythrocyte G-6-P.D. deficiency, the average activity of this enzyme in younger cell fractions was significantly higher than in comparable samples prepared from severely affected Caucasians (Table IV). Among these affected Negroes, G-6-P.D. activities in the younger cell fractions did not approach values obtained for control subjects. Nevertheless, enzyme activity, on the average, was 7.4 times higher in the young compared with the old red cell fraction. Caucasians with very low G-6-P.D. activities in the whole erythrocyte population generally had little detectable enzyme activity in the younger cell fractions and relatively small differences between these erythrocyte samples and older cell fractions. 
In Negroes with a moderate decrease in erythrocyte G-6-P.D. activity, the mean value for the enzyme in younger compared with the older erythrocyte fractions differed by a factor of 4.0 (Table IV).

\section{Enzyme activity in erythrocytes fractionated by centrifugation}

To examine further the effect of aging on enzyme activity in affected compared with control subjects, red blood cells from persons with a reticulocytosis were fractionated by centrifugation. This technique provides populations of cells enriched with young and old erythrocytes in an unlysed state permitting a determination of the reticulocyte count in the samples of erythrocytes assayed for enzyme activity.
In control subjects and persons with an increased percentage of reticulocytes, the level of G-6-P.D. was higher in the upper (younger) than in the lower (older) erythrocyte fractions (Table V). As previously observed (14), patients with reticulocytosis compared with control subjects, have higher levels of G-6-P.D. in their whole erythrocyte population as well as in the relatively younger and older red cell fractions. The fractions of erythrocytes of relatively young and older mean cell age separated by centrifugation showed smaller differences in enzyme activity than did the fractions of differing mean cell age prepared by serial osmotic hemolysis. This finding, too, is in agreement with earlier published data (12).

In two Negro subjects with marked erythrocyte

TABLE V

Glucose-6-phosphate dehydrogenase activity in erythrocyte fractions of different mean cell age separated on the basis of varying density

\begin{tabular}{|c|c|c|c|c|c|c|c|}
\hline \multirow[b]{2}{*}{ Subject* } & \multirow[b]{2}{*}{ Race } & \multicolumn{2}{|c|}{ WEPt } & \multicolumn{2}{|c|}{ Top $3 \%$ cells $\ddagger$} & \multicolumn{2}{|c|}{ Bottom $3 \%$ cells } \\
\hline & & $\begin{array}{l}\text { Reticu- } \\
\text { locyte } \\
\text { count }\end{array}$ & G-6-P.D. & $\begin{array}{l}\text { Reticu- } \\
\text { locyte } \\
\text { count }\end{array}$ & G-6-P.D. & $\begin{array}{l}\text { Reticu- } \\
\text { locyte } \\
\text { count }\end{array}$ & G-6-P.D. \\
\hline Normals & & & & & & 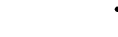 & \\
\hline $\begin{array}{l}1 \\
2 \\
3 \\
4 \\
5 \\
6 \\
7\end{array}$ & $\begin{array}{l}\mathrm{C} \\
\mathrm{C} \\
\mathrm{C} \\
\mathrm{C} \\
\mathrm{N} \\
\mathrm{N} \\
\mathrm{N}\end{array}$ & $\begin{array}{l}0.4 \\
0.5 \\
0.8 \\
0.8 \\
0.9 \\
0.9 \\
0.7\end{array}$ & $\begin{array}{l}12.4 \\
17.0 \\
19.4 \\
15.9 \\
14.1 \\
14.4 \\
15.9\end{array}$ & $\begin{array}{l}0.2 \\
0.6 \\
1.7 \\
2.6 \\
1.1 \\
3.6 \\
1.1\end{array}$ & $\begin{array}{l}21.6 \\
24.7 \\
30.1 \\
30.0 \\
20.9 \\
21.8 \\
24.3\end{array}$ & $\begin{array}{r}0.0 \\
0.3 \\
0.0 \\
0.2 \\
0.2 \\
1.1 \\
\\
0.3\end{array}$ & $\begin{array}{r}14.9 \\
14.7 \\
17.7 \\
10.5 \\
12.3 \\
9.7 \\
12.9\end{array}$ \\
\hline Mean & & 0.7 & 15.6 & 1.6 & 24.8 & 0.3 & 13.2 \\
\hline \multicolumn{8}{|c|}{ Reticulocytosis with high enzyme activity } \\
\hline $\begin{array}{r}8 \\
9 \\
10 \\
11 \\
12 \\
13\end{array}$ & $\begin{array}{l}\mathrm{C} \\
\mathrm{C} \\
\mathrm{C} \\
\mathrm{N} \\
\mathrm{N} \\
\mathrm{N}\end{array}$ & $\begin{array}{r}13.6 \\
15.4 \\
68.0 \\
6.0 \\
3.9 \\
79.0\end{array}$ & $\begin{array}{l}25.9 \\
22.2 \\
22.9 \\
20.2 \\
29.0 \\
27.9\end{array}$ & $\begin{array}{r}42.0 \\
51.1 \\
98.0 \\
6.9 \\
8.1 \\
88.0\end{array}$ & $\begin{array}{l}49.6 \\
38.4 \\
62.0 \\
31.0 \\
40.5 \\
48.4\end{array}$ & $\begin{array}{r}0.2 \\
0.3 \\
30.0 \\
0.9 \\
0.3 \\
10.0\end{array}$ & $\begin{array}{l}18.2 \\
20.4 \\
18.2 \\
18.3 \\
23.6 \\
22.7\end{array}$ \\
\hline Mean & & 31.0 & 24.7 & 39.0 & 45.0 & 7.0 & 20.2 \\
\hline \multicolumn{6}{|c|}{ Reticulocytosis with low enzyme activity } & & \\
\hline $\begin{array}{l}14 \\
15 \\
16 \\
17\end{array}$ & $\begin{array}{l}\mathrm{C} \\
\mathrm{C} \\
\mathrm{N} \\
\mathrm{N}\end{array}$ & $\begin{array}{r}18.2 \\
2.9 \\
4.0 \\
3.9\end{array}$ & $\begin{array}{l}0.3 \\
0.5 \\
3.2 \\
1.1\end{array}$ & $\begin{array}{r}23.9 \\
7.1 \\
8.3 \\
13.9\end{array}$ & $\begin{array}{l}1.5 \\
0.9 \\
6.5 \\
8.0\end{array}$ & $\begin{array}{l}3.8 \\
0 \\
0.7 \\
0.7\end{array}$ & $\begin{array}{l}0 \\
0 \\
2.0 \\
0\end{array}$ \\
\hline
\end{tabular}

* Subjects with reticulocytosis included persons with chronic hemolytic anemia of undetermined etiology (Subjects $8,9,10,13$ and 14) and patients with anemia secondary to bleeding from a peptic ulcer (Subjects 11, 12, 16 and 17). Patient 15 had no other clinically apparent hematological abnormality.

$\dagger$ Abbreviations: see Footnote *, Table III.

$\$$ The top 3 per cent cells, erythrocyte fractions with younger mean cell age, and the bottom 3 per cent cells, erythrocyte fractions with older mean cell age, were prepared according to the method indicated in the text. The top $3 \%$ cells compared to the bottom $3 \%$ cells generally contained a larger number of leukocytes relative to the erythrocyte concentration. Accordingly, all erythrocyte enzyme activities presented in this table represent values which are corrected for the dehydrogenase activity attributable to the white blood cells present in the red blood cell samples. See text for the details of the calculation of this correction. 
G-6-P.D. deficiency, younger red cell fractions were obtained with reticulocyte counts of 8.3 and 13.9 per cent, respectively. G-6-P.D. activities were distinctly higher in these younger compared with the older cells (Table V, Subjects 16 and 17). By comparison, in two severely affected Caucasian subjects, the younger cell fractions, with 23.9 and 7.1 per cent reticulocytes, respectively, had little G-6-P.D. activity.

\section{DISCUSSION}

Erythrocyte G-6-P.D. deficiency was first demonstrated by Carson, Flanagan, Ickes and Alving (20) in Negro subjects who had an increased susceptibility to hemolysis following primaquine administration. Subsequently, this trait (measured by reduced glutathione stability or G-6-P.D. activity in red cells) has been recognized among certain Caucasian, as well as other Negro populations (1-10). It is most likely that this enzyme deficiency is due to a sex-linked gene of intermediate dominance $(4,5,9)$. The present study indicates that there is a significant quantitative difference between Caucasians and Negroes who have a deficiency in G-6-P.D. Thus, G-6-P.D. activity is markedly lower in the whole erythrocyte population, the young red cells and the leukocytes of affected Caucasian males compared with affected Negro males. A review of previously published data $(5,21-26)$ reveals that affected Caucasian males were generally reported to have markedly low, or undetectable levels of G-6-P.D., while affected Negro males were rarely observed with levels below 10 per cent of the control mean value. ${ }^{3}$

Affected Negro and Caucasian females were found not to differ significantly with respect to the degree of red cell enzyme deficiency. This may reflect the fact that affected females are predominantly heterozygous. In heterozygotes, the presence of a single normal gene could mask quantitative differences in the enzyme activity which might result from different mutant genes.

Numerous investigations, primarily with Neurospora and certain bacteria (27-32), have provided evidence which suggests that a given functional

\footnotetext{
3 Ramot, Szeinberg and Sheba have observed that among Israeli subjects with erythrocyte G-6-P.D. deficiency, the level of this enzyme in leukocytes was significantly below that of a control group (personal communication).
}

genetic unit controls the formation of only one enzyme. Such studies have also provided examples of organisms in which two or more different mutants have been found to be deficient in the same enzyme (28-31). On the basis of these observations, several genetic mechanisms could account for the quantitative difference between Caucasians and Negroes. Thus, these findings could represent different mutations occurring in the same region on the $\mathrm{X}$ chromosome concerned with the formation of G-6-P.D.

On the other hand, these differences might reflect the fact that more than one gene may affect the level of G-6-P.D. activity. It has been suggested that such genetic modifiers may be concerned with repair of an altered enzyme or with control of various quantitative aspects of enzyme formation or function (29). Conceivably, there is a second mutation in affected Negroes which results in partial restoration of enzyme activity.

Another possibility, based on findings such as those of Umbarger and Brown (33), is that two or more distinctly different proteins may be produced which catalyze the same reaction, in this instance, the oxidation of glucose-6-phosphate. The quantitative difference between affected Caucasians and Negroes might then represent mutations involving different genes controlling the formation of the different proteins. Such mutations might result in varying degrees of decrease in the amount of enzyme activity.

The effects of a mutation which lead to a deficiency in enzyme activity appear to fall into at least two categories : $a$ ) partial or complete failure to produce the enzyme $(27-32)$, or $b$ ) formation of a qualitatively altered protein (34-37). A partial or complete block in enzyme synthesis could result from either one of the genetic mechanisms mentioned above. However, in affected Negroes, the finding of normal, or near normal, G-6-P.D. activities in leukocytes suggests that, at least in this group, a block in the formation of this enzyme may not be the cause of the decreased levels of red cell enzyme.

Among affected subjects, G-6-P.D. deficiency was more marked in erythrocytes than in white cells. It has been suggested that a gene action leading to a formation of an altered enzyme of reduced stability would be compatible with these findings (11). In red cells, which synthesize little 
or no protein, a faster than normal rate of decline in enzyme activity with aging in vivo could lead to a more marked deficiency of this enzyme in erythrocytes than in tissues which can synthesize proteins.

The evidence obtained in this study is inconclusive as to whether or not, in affected subjects, G-6-P.D. activity decreases more rapidly than normal with red cell aging. In normal and severely affected Negroes, G-6-P.D. activity in young compared with old erythrocyte fractions differed by essentially the same factor. However, in many of these affected subjects and in all of the severely affected Caucasians studied, the enzyme activity in the young cell fractions was very low. Accordingly, it is difficult to evaluate the meaning of the relatively small differences in enzyme activity between erythrocyte fractions enriched with young or old cells. These results could be compatible with erythrocyte G-6-P.D. deficiency being secondary to either $a$ ) a block in enzyme synthesis without any necessary alteration in its rate of degradation, or $b$ ) a more rapid than normal decrease in enzyme activity resulting in low levels in the very young red cell. In the latter case, G-6-P.D. activity in young cell fractions being very low, the relative differences between young and old cells might even be less than normal.

Studies by Kirkman (38) and in this laboratory (39) have, to date, revealed no difference in the properties of the G-6-P.D. purified from red cells of normal and of affected Negroes. Thus, the enzymes were found to have identical affinities for their substrates, glucose-6-phosphate and triphosphopyridine nucleotide, various triphosphopyridine nucleotide analogs, and $\mathrm{pH}$ optima. However, erythrocyte G-6-P.D. of affected compared with that of normal subjects has a greater heatlability upon incubation of crude hemolysates at $37^{\circ} \mathrm{C}$. $(21,40-42)$. This heat-lability of the enzyme from affected subjects is markedly decreased by addition of triphosphopyridine nucleotide (42). No evidence has been obtained to indicate that the difference in heat-lability between the normal and mutant enzymes reflects the presence of an inbibitor or lack of an activator in red cells of affected subjects $(2,39)$. It is possible that in affected Negroes (data on the enzyme purified from affected Caucasians are lacking) an altered enzyme is formed which, although unchanged in the specificity of its catalytic site, has a decreased stability at $37^{\circ} \mathrm{C}$.

The present data permit no conclusions as to which, if any, of the above indicated genetic mechanisms accounts for the quantitative difference between affected Negroes and Caucasians. Further, the affected Negro and the affected Caucasian group may in themselves be genetically heterogeneous. However, it seems likely that elucidation of the mechanism of erythrocyte G-6P.D. deficiency affords a model for extending our understanding of the nature of gene action in human subjects.

It is pertinent to point out that this study provides no information as to the relationship between erythrocyte G-6-P.D. deficiency and sensitivity to hemolysis. As summarized in recent reviews (1, $2,19)$, the elucidation of certain biochemical abnormalities in red cells of drug sensitive subjects has not established the mechanism of their increased susceptibility to hemolysis. Accordingly, it is not possible to answer the question of whether the quantitative differences between affected Caucasians and Negroes is correlated with variations in the clinical course of the hemolytic reaction.

\section{SUMMARY}

Among subjects with a genetically determined deficiency in glucose-6-phosphate dehydrogenase (G-6-P.D.), there is a quantitative difference between Caucasians and Negroes. Affected Caucasian males compared with affected Negro males were found to have a significantly lower G-6-P.D. activity in the whole erythrocyte population, the young red cells, and the leukocytes. In affected Negro subjects, G-6-P.D. activities in young red cells, though not approaching control levels, were distinctly higher than in old cells. Caucasian males, whose whole erythrocyte population had little or no detectable G-6-P.D. activity, showed relatively small differences in the amount of enzyme activity detectable in young compared with old cells. It is suggested that different genetic mechanisms account for the deficiency of G-6-P.D. in Negroes and in Caucasians.

\section{ACKNOWLEDGMENTS}

The authors are grateful to the following physicians who kindly provided subjects for this study: Dr. Helen 
Ranney, Department of Medicine, College of Physicians and Surgeons, Columbia University and Dr. Theodore Spaet, Montefiore Hospital, New York City; and to Dr. Denman Hammond, Los Angeles Children's Hospital, Los Angeles. The authors are indebted to Dr. Anne B. Johnson for her assistance during the course of this study. Miss Dawn Bunnell provided valuable technical assistance.

\section{REFERENCES}

1. Beutler, E. The hemolytic effect of primaquine and related compounds: A review. Blood 1959, 14, 103.

2. Marks, P. A., and Gross, R. T. Drug-induced hemolytic anemias and congenital galactosemia: Examples of genetically determined defects in erythrocyte metabolism. Bull. N. Y. Acad. Med. 1959, 35, 433.

3. Beutler, E. The glutathione instability of drugsensitive red cells: A new method for the in vitro detection of drug sensitivity. J. Lab. clin. Med. 1957, 49, 84.

4. Childs, B., Zinkham, W., Browne, E. A., Kimbro, E. L., and Torbert, J. V. A genetic study of a defect in glutathione metabolism of the erythrocyte. Bull. Johns Hopk. Hosp. 1958, 102, 21.

5. Gross, R. T., Hurwitz, R. E., and Marks, P. A. An hereditary enzymatic defect in erythrocyte metabolism: Glucose-6-phosphate dehydrogenase deficiency. J. clin. Invest. 1958, 37, 1176.

6. Motulsky, A. G., and Campbell, J. M. A screening test for glucose-6-phosphate dehydrogenase deficiency of the red cell suitable for genetic surveys. Possible relationship of the enzyme defect to malaria. Blood. In press.

7. Keller, J., Pi-Sunyer, X., Plaut, T., and Marks, P. A. Incidence of erythrocyte glucose-6-phosphate dehydrogenase deficiency among different population groups in Surinam. In preparation.

8. Zinkam, W. H., Lenkard, R. E., Jr., and Childs, B. A deficiency of glucose-6-phosphate dehydrogenase activity in erythrocytes from patients with favism. Bull. Johns Hopk. Hosp. 1958, 102, 169.

9. Szeinberg, A., Sheba, C., and Adam, A. Selective occurrence of glutathione instability in red blood corpuscles of the various Jewish tribes. Blood $1958,13,1043$.

10. Beutler, E., Yeh, M. K. Y., and Necheles, T. Incidence of the erythrocyte defect associated with drugsensitivity among oriental subjects. Nature (Lond.) 1959, 183, 684.

11. Marks, P. A., Gross, R. T., and Hurwitz, R. E. Gene action in erythrocyte deficiency of glucose-6phosphate dehydrogenase: Tissue enzyme-levels. Nature (Lond.) 1959, 183, 1266.

12. Marks, P. A., Johnson, A. B., and Hirschberg, E. Effect of age on the enzyme activity in erythrocytes. Proc. nat. Acad. Sci. (Wash.) 1958, 44, 529.
13. Kornberg, A., and Horecker, B. L. Glucose-6-phosphate dehydrogenase in Methods in Enzymology, S. P. Colowick, and N. O. Kaplan, Eds. New York, Academic Press Inc., 1955, vol. 1, p. 323.

14. Marks, P. A. Red cell glucose-6-phosphate and 6-phosphogluconic dehydrogenases and nucleoside phosphorylase. Science 1958, 127, 1338.

15. Allison, A. C., and Burn, G. P. Enzyme activity as a function of age in the human erythrocyte. Brit. J. Haemat. 1955, 1, 291.

16. Smith, L. H., Jr., and Baker, F. A. Pyrimidine metabolism in man. I. The biosynthesis of orotic acid. J. clin. Invest. 1959, 38, 798.

17. Marks, P. A., and Johnson, A. B. Relationship between the age of human erythrocytes and their osmotic resistance: A basis for separating young and old erythrocytes. J. clin. Invest. 1958, 37, 1542.

18. Borun, E. R., Figueroa, W. G., and Perry, S. M. The distribution of $\mathrm{Fe}^{\infty}$ tagged human erythrocytes in centrifuged specimens as a function of cell age. J. clin. Invest. 1957, 36, 676.

19. Alving, A. S., Kellermeyer, R. W., Tarlov, A., Schrier, S., and Carson, P. E. Biochemical and genetic aspects of primaquine-sensitive hemolytic anemia. Ann. intern. Med. 1958, 49, 240.

20. Carson, P. E., Flanagan, C. L., Ickes, C. E., and Alving, A. S. Enzymatic deficiency in primaquinesensitive erythrocytes. Science 1956, 124, 484.

21. Szeinberg, A., Sheba, C., and Adam, A. Enzymatic abnormality in erythrocytes of a population sensitive to Vicia faba or haemolytic anaemia induced by drugs. Nature (Lond.) 1958, 181, 1256.

22. Waller, H. D., Löhr, G. W., and Tabatabai, M. Hämolyse und Fehlen von Glucose-6-Phosphate dehydrogenase in roten Blutzellen (Eine Fermentanomalie der Erythrocyten). Klin. Wschr. 1957, 35, 1022.

23. Schrier, S. L., Kellermeyer, R. W., Carson, P. E., Ickes, C. E., and Alving, A. S. The hemolytic effect of primaquine. IX. Enzymatic abnormalities in primaquine-sensitive erythrocytes. J. Lab. clin. Med. 1958, 52, 109.

24. Sansone, G., and Segni, G. Nuovi aspetti dell'alterato biochimismo degli eritrociti di favici : Assenza pressoche' completa della glucose-6-P deidrogenasi. Boll. Soc. ital. Biol. sper. 1958, 34, 327.

25. Larizza, P., Brunetti, P., Grignani, F., and Ventura, S. L'Individualità bioenzimatica dell'eritrocito "fabico"; sopra alcune anomalie biochimiche ed enzimatiche delle emazie nei pazienti affetti da favismo e nei loro familiari. Haematologica 1958, 43, 205.

26. Dawson, J. P., Thayer, W. W., and Desforges, J. F. Acute hemolytic anemia in the newborn infant due to naphthalene poisoning: Report of two cases, with investigations into the mechanism of the disease. Blood 1958, 13, 1113.

27. Beadle, G. W. Biochemical genetics. Chem. Rev. 1945, 37, 15. 
28. Beadle, G. W. The role of the nucleus in heredity in A Symposium on The Chemical Basis of $\mathrm{He}$ redity, W. D. McElroy and B. Glass, Eds. The Johns Hopkins Press, Baltimore, 1957, p. 3.

29. Yanofsky, C., and Bonner, D. M. Gene interaction in tryptophan synthetase formation. Genetics 1955, 40, 761.

30. Demerec, M., and Hartman, Z. Tryptophan mutants in salmonella typhimurium in Genetic Studies with Bacteria. Washington, Carnegie Inst., 1956, Pub. 612 , p. 5.

31. Horowitz, N. H., and Fling, M. The role of the genes in the synthesis of enzymes in Enzymes, Units of Biological Structures and Function, O. H. Gaebler, Ed. New York, Academic Press Inc., 1956, p. 139.

32. Lederberg, J. Comment on gene-enzyme relationship in Enzymes, Units of Biological Structure and Function, O. H. Gaebler, Ed. New York, Academic Press Inc., 1956, p. 161.

33. Umbarger, H. E., and Brown, B. Threonine deamination in Escherichia coli: II. Evidence for two L-Threonine deaminases. J. Bact. 1957, 73, 105.

34. Pauling, L., Itano, H. A., Singer, S. J., and Wells, I. C. Sickle cell anemia, a molecular disease. Science 1949, 110, 543.

35. Maas, W. K., and Davis, B. D. Production of an altered pantothenate-synthesizing enzyme by a tem- perature-sensitive mutant of Escherichia coli. Proc. nat. Acad. Sci. (Wash.) 1952, 38, 785.

36. Horowitz, N. H., and Fling, M. Genetic determination of tyrosine thermostability in neurospora. Genetics 1953, 38, 360.

37. Ingram, V. M. Chemistry of the abnormal human haemoglobins. Brit. med. Bull. 1959, 15, 27.

38. Kirkman, H. N. Characterization of partially purified glucose-6-phosphate dehydrogenase from normal and primaquine-sensitive erythrocytes. Fed. Proc. 1959, 18, 261.

39. Marks, P. A. Comments on studies on erythrocyte glucose-6-phosphate dehydrogenase deficiency in A Symposium on Molecular Genetics and Human Disease, L. I. Gardner, Ed. In press.

40. Carson, P. E., Schrier, S. L., and Alving, A. S. Inactivation of glucose-6-phosphate dehydrogenase in human erythrocytes (abstract). J. Lab. clin. Med. 1956, 48, 794.

41. Motulsky, A. G., Kraut, J. M., Thieme, W. T., and Musto, D. F. Biochemical genetics of glucose-6phosphate dehydrogenase deficiency (abstract). Clin. Res. 1959, 7, 89.

42. Marks, P. A., and Gross, R. T. Further characterization of the enzymatic defect in erythrocyte glucose-6-phosphate dehydrogenase deficiency: A genetically determined trait (abstract). J. clin. Invest. $1959,38,1023$. 